\title{
Cecimpedan: Semantic-cognitive Process on Balinese Children
}

\author{
Nengah Arnawa \\ Faculty of Language and Art Education, IKIP PGRI Bali, Jalan Seroja, Tonja, Denpasar Utara, Bali, Indonesia
}

\begin{abstract}
Cecimpedan is a kind of riddle in Balinese language. Cecimpedan can be classified into two types, namely onomatope and associative cecimpedan. The classification is based on linear cognitive development with the linguistic competence of children. Onomatope cecimpedan is used by children who are in the preoperational cognitive developmental period whereas associative cecimpedan is used by children who are in formal operational period. The hierarchy of cognitive development motivates the difference of syntactic and semantic constructions within those two kinds of cecimpedan. The semantic process of onomatope cecimpedan involves the logic of inductive analogy that holds on the actual similarity between rhyme and sound resonance of a word. Rhyme and sound resonance are formed through abbreviation process by maintaining the final syllable of a word. It is in opposite with associative cecimpedan. This second type of cecimpedan was developed by using declarative analogy logic. It is constructed through lexical choices that can lead to semantic disparity. This semantic disparity becomes the core of associative cecimpedan. Therefore, each participant must be able to clarify the answer of associative cecimpedan logically and empirically.
\end{abstract}

Index Terms - cecimpedan, semantic process, onomatope, associative, cognitive development

\section{INTRODUCTION}

Cecimpedan is one of the Balinese proverbs used by children when playing in opposition, both between individuals and between groups. Cecimpedan can be classified into a riddle through syntactic and semantic construction games. The use of cecimpedan involves two parties that alternately act as speaker and hearer. The speaker encodes the meaning into a question, while the hearer decodes the question into meaning. The speaker reveals a construction of cecimpedan and becomes the hearer's duty to interpret its meaning. The interaction of speaker and hearer involves different cognitive processes, namely the process of speech production and understanding (Tantra, 1992). The winner is determined through the number of cecimpedan that can be interpreted correctly by the opposing party in a given time unit. The cognitive semantic process that occurs at the time of production and understanding of the cecimpedan becomes the focus of this study.

Example 1.

Cecimpedan: Apa cing kong?

'What is cing kong?'

Answer: Cicing ngongkong.

Example 2.

'Dog is barking'

Cecimpedan: Apa mirah asibuh?

'What is one ruby'

Answer: Buah delima.

'Pomegranate (Latin : punica granatum).

The cecimpedan pattern as in Example 1 is commonly used by children at the end of the pre-operational cognitive development phase until the concrete operational phase; Whereas the cecimpedan as in Example 2 is commonly used by children in the formal operational cognitive development phase. The difference in construction illustrates that there is a complexity hierarchy of cognitive role. Besides those two cecimpedan constructions as examples 1 and 2 above, there is another riddle in the Balinese proverb which is expressed through a poem by using pupuh pucung. This enigmatic poem is called cecangkriman commonly used by adult speakers. As this study focuses on the cognitive semantic processes of children, they will be examined on other occasions.

As a form of a Balinese proverb, the cecimpedan is contained in the Balinese language curriculum at the Elementary School; Therefore, the teacher must teach it. The problem arises in the learning process. Cecimpedan is taught by memorizing the syntactic and semantic constructions. Such way of learning cecimpedan does not actively involve children cognitive. As a result, children fail to produce new cecimpedan and seems like a recycling process. To solve this issue, the active involvement of children's cognitive is important. The way is by explaining the semantic-cognitive process that occurs in cecimpedan. This is the focus of this study.

\section{THEORETICAL CONSTRUCTION}


Based on the basic concepts of structural linguistics developed by Saussure (1988) and Bloomfield (1995), each lingual unit consists of signs and markers. Cecimpedan can be seen from both aspects. The construction of a question in a cecimpedan is a sign aspect (signifiant) while its semantic interpretation is a marker aspect (signifie). Sign and marker relationships are tied up by decoding and encoding processes played by the participants alternately. Cognitive processes in encoding and decoding cecimpedan are the focus of this study.

The cognitive process can be viewed as a mental activity to connect, assess, and consider something in a person and his/her environment. Cognitive process is thoughtful activities to recognize and give a rationale reason for a stimulus so that one can make decision. The accuracy of the taken decision is based on the human primary ability, which includes: language skills, recall, reasoning or logical thinking, space understanding, number comprehension, word usage, and quick and thorough observation. All elements of primary ability are blended used to take the conclusion (Sujiono, et al., 2009). As a cognitive process, thinking is the most important basic potential that distinguishes human beings from other livings. Thinking is an activity of organizing information obtained from the environment to solve problems encountered through formal reasoning to the decision-making process. Listening and observing skills based on consistent logic are the implementation of formal reasoning. Formal reasoning allows one to identify to produce a classification of something (Crider, et al., 1983). This mechanism of formal reasoning is expected to explain the semantic processes that occur in children when using cecimpedan.

Cecimpedan is also often seen as a Balinese language game for children. In language games, speakers manipulate linguistic forms at various levels (Sherzer, 1976). In the case of cecimpedan, the speaker manipulates the lexical level. Manipulation is done in two ways. First, the omission of one or several syllables so that only retain one last syllable. The defense of last syllable is intended to obtain the final rhyme as a basis of semantic interpretation. For example, the noun kocor 'water container made of coconut shell' is manipulated into cor; as well as the verb megantung 'hanging' is manipulated into tung so it produces a construction of cecimpedan 'Apa cor tung?' 'What is cor tung?' Second, hide a lexical, phrase, or clause by constructing it into a question. Questions are constructed based on a formal analogy. For example, 'Apa panakne jekjek, memene slelegang?' 'What is it, the children are trampled while the mother is propped up?' The meaning is 'a man stepped up the stairs'. As one form of language play (speech play), cecimpedan relies on the accuracy of keyword guess that speakers have manipulated. Cecimpedan requires the speaker to select the vocabulary and knowledge behind the use of everyday language (ordinary language). The speaker must be able to accurately predict the implicature of verbal forms that have been manipulated by the speakers through sound changes and other linguistic characteristics (Gimblett, 1976, Hall, et al., 1977).

The language game by children is very different from the adult language. The study of children's language games is closely related to cognitive development. Piaget formulates the four stages of child cognitive development. The first is the sensorimotor period that occurs in children aged 0-2 years. The cognitive development of sensorimotor period is characterized by the change of reflex motion into a coordinated body motion as a response to the received stimulus. In this period, the child's memory is not perfect yet. Language development is characterized by the ability to produce sentences of one to two words and still be telegraphic. In this phase, Balinese children cannot play cecimpedan. The second is the preoperational period that is happened in children aged 2-7 years. The cognitive development in this period is characterized by concrete thinking. Since children of 4 or 5 years, they experience a rapid development of language which is characterized by mastery of basic grammatical construction. This language skill encourages wider thinking skills. At the end of this period, Balinese children can already be invited to play cecimpedan of pattern 1 . The third is concrete operational period that is happened in children aged 7-11 years. In this period, children have the ability to classify things into groups or subgroups. The child has been able to compare something to something else. Simple reasoning begins to develop that is characterized by the ability to understand conversions, and the language development has led to adult grammar. In this period, Balinese children have been able to play cecimpedan both pattern 1 and pattern 2. The fourth is formal operational period that is lasted at the age of 11-14 years. In this period, children can already think abstractly and logically, like adults, including in language (Chaer, 2003; Sund, 1976). In this period, children often participate in cecimpedan competition of pattern 2. The study of cecimpedan is expected to be a model of children's language game research in a traditional cultural frame. This study is directed on cognitive semantic mechanism as children produce (encode) and understand (decode) cecimpedan by focusing on manipulated linguistic instruments as well as associative reasoning.

The cognitive process of producing (encoding) utterance consists of four stages, namely message level, functional level, positional level, and phonological level. At the message level phase, children determine the meaning of conveyed utterance. This phase is often called the initial semantic graph. At the functional phase, the children choose the linguistic devices, such as lexical and syntactical structure to be used to explain meaning. This phase is relevant to the principle of inner speech in children. Furthermore, the positional level phase is the cognitive process of arranging the words order to be sentences according to the rules of morpho syntax. This cognitive process is the utterance plan. Finally, the phonological phase is the process of encoding the concept into a real utterance that can be heard by the hearer. At this stage, the child has done the formation of an expanded speech utterance (Dardjowidjojo, 2003; Luria, 1982).

The comprehension of utterance meaning is a mental activity when a child or group of children perceives the utterance that he or she hears. In this study, comprehension is defined as a comprehension of utterance being heard. 
Comprehension is based on the child's ability to perceive the deep structures and the surface structure of the sentence. Comprehension of the deep structure and surface structure of the sentence leads the child to the conclusion that the meaning of a sentence is not only determined by the choice of used words but also by background knowledge and psychological reality, syntactic factors, and semantic strategy (Dardjowidjojo, 2003).

Based on the basic concepts of cognitive process, the study examines the cognitive mechanism that children use when encoding and decoding cecimpedan. The explanation of cognitive process when encoding and decoding becomes very significant to describe the semantic process occurred in the cecimpedan. Comprehension of cognitive and semantic processes is expected to create construction and interpretation of cecimpedan in a more creative and dynamic way as one of the language characteristics that is alive and used by its speaker community.

Cecimpedan is a speech culture (oral) in Balinese society. As a form of speech, the semantic interpretation of cecimpedan also involves the study of discourse and pragmatics. Discourse theory can frame the natural context of cecimpedan construction that is tied to its text and context; Whereas the concept of locution, illocution, and perlocution of pragmatic theory can guide the speaker's mind when giving his semantic interpretation.

Based on the above explanation, the theory construction of this study can be visualized as follows.

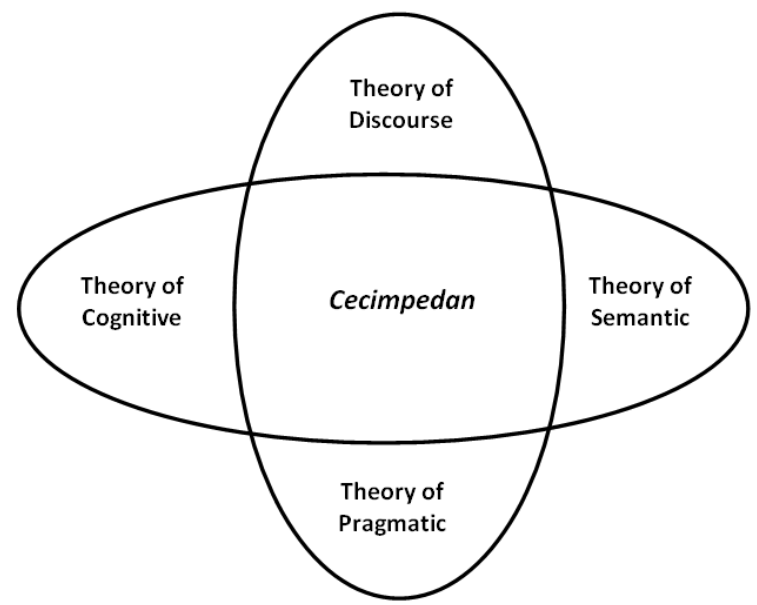

Diagram 1. Theoretical Construction

\section{METHOD}

This study is designed in qualitative research design which emphasis on syntactic and semantic aspects of a natural language context. The research procedure is carried out inductively and oriented on the cognitive process. Data were collected by document recording method through field notes, video recording, and written documents (Samarin, 1988; Sudaryanto, 1993; Djajasudarma, 1993; Mashun, 2005). The data are taken from: (1) video recording with 120 minutes duration of cecimpedan competition held by PGRI Foundation Denpasar in 2014; recording with 120 minutes duration, cecimpedan competition at the 37th of Bali Arts Festival in 2015; and written documents of Balinese proverbs from various books, such as (Tinggen, 1995; Ginarsa, 1985; Simpen, 1988). From the data source, it was collected 30 units cecimpedan patterned as example 1 and 121 units patterned as example 2. Selection of data is done purposively so it produces core corpus. From all data which are collected randomly, classification is done by considering the syntactic and semantic construction patterns. Based on the classification, the data are selected and the unit of cecimpedan are assigned as a representation of the corpus totality. The core corpus validation process is done by triangulation technique through exclusive interviews to Balinese language experts, Balinese language teachers in Elementary School, and children. Data ws analyzed based on the comparison of morpho-phonological constructions and the syntactical of cecimpedan unit with its referential semantics. Based on the comparison, it can be expressed the cognitive processes that occur at the time of cecimpedan production and comprehension.

\section{DATA ANALYSIS}

\section{A. The Classification of Cecimpedan}

Balinese practitioners generally classify cecimpedan based on the age group of its users, so it is identified as a cecimpedan alit-alit 'children cecimpedan' used by children under 10 years and cecimpedan biasa 'regular cecimpedan' used by children over 10 years (Tinggen 1995, Gautama 1995, Simpen, 1988, Ginarsa, 1985). Against this classification, the following critical views can be given. First, there is no sufficient explanation to the use of age 10 to be a barrier. The development of semantic and language is not merely related to age, but is more related to the cognitive developmental phases. Moreover, in practice, the age limit is often unclear or ruled out. Second, the terminology used is not symmetrical, i.e. cecimpedan alit-alit 'children cecimpedan' and cecimpedan biasa 'regular cecimpedan'. The word 
alit-alit refers to age whereas the word biasa does not. It shows that the basis of classification is not clear. Therefore, this study develops different classification bases. In this study, cecimpedan are classified according to word construction and its syntactical structure, so they are identified as onomatope and associative cecimpedan.

Onomatope cecimpedan has a single pattern. The syntactic construction tends to be the same, i.e. apa $+\mathrm{x} y$; $\mathrm{x}$ and $\mathrm{y}$ are the final term (abbreviation) of two words. The defense of word last syllable is based on intimate style of Balinese oral language culture. The defense of word last syllable will produce rhyme as a semantic interpretation. In a relaxed and intimate atmosphere, Balinese speakers often make abbreviation on certain word pronunciations. In this linguistic event, the final syllable of the word is usually retained, as the following examples.

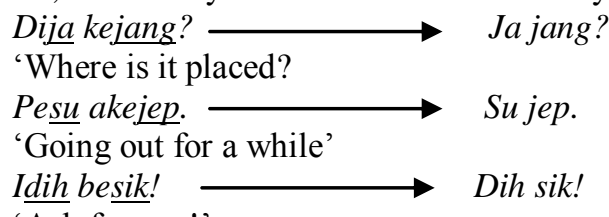

'Ask for one!'

Besides those examples, the defense of word final syllable also occurs in the Balinese greeting. The word bapa 'father' is shortened to be pa; meme 'mother' to be me; dadong 'grandmother' to be dong; kaki 'grandfather' to be ki; wayan '1st child' to be yan, nengah '2nd child' to be ngah, nyoman '3rd child' to be man, ketut '4th child' to be tut, and others. The final syllable defense of a word is a latent inherent from the first language acquisition. From the age of two years, the child is able to produce a single word utterance by maintaining the final syllable and deleting the syllable in front of it (Dardjowidjojo, 2000, Garman, 1991). Genetically, the Balinese language belongs to the western Austronesian language family. In this language family, final intonation is often used as a determinant of meaning. This historical fact, linguistics and culture give the reason of the final syllable defense in the process of onomatope cecimpedan formation. The following is presented some data of onomatope cecimpedan.

TABEL 1.

THE COMPARISON OF ONOMATOPE CECIMPEDAN AND ORDINARY LANGUAGE

\begin{tabular}{lll}
\hline \hline No. & Onomatope Cecimpedan & Ordinary Language \\
\hline 1. & Apa cor tung? & kocor magantung \\
& 'What is cor tung?' & 'shell is hanged' \\
2. & Apa jog keng? & 'mog mapangkeng \\
& 'What is jog keng?' & 'monkey is caged' \\
3. & Apa cing kong? & 'dong ngongkong \\
& 'What is cing kong?' & capung makonceng \\
4. & Apa pung ceng? & 'dragonfly is flushing' \\
& 'What is pung ceng?' & bedeg magantung \\
5. & Apa deg tung? & 'bamboo basket is hanged' \\
\end{tabular}

In contrast to onomatope cecimpedan, associative cecimpedan has varying constructions. This cecimpedan does not use word abbreviations, but the full word, either with or without morphological processes. The number of words in each unit can be more than three. The questions used can be single or plural clause; even can be constructed into short paragraph therefore associative cecimpedan can be paraphrased. It is called associative cecimpedan because it involves cognitive links to people, events, or something else that results in the linking of ideas. The linking of ideas occurs because of a matching exposure of one idea to another idea (Alwi, et al. 2001; Hari and Indrayani, 2010). The association process is supported by declarative reasoning which allows an explanation of the association. Some data of associative cecimpedan can be presented below. 
TABEL 2.

ASSOCIATIVE CECIMPEDAN AND ITS MEANING

\begin{tabular}{|c|c|c|}
\hline No. & Associative Cecimpedan & Meaning \\
\hline \multirow[t]{2}{*}{1.} & Apa anak cenik maid cacing? & jaum \\
\hline & 'What is it, a child is pulling a worm?' & 'needle' \\
\hline \multirow[t]{2}{*}{2.} & Apa lipi gadang mroko? & Ubad legu \\
\hline & 'What is it, a green snake is smoking?' & 'mosquitto repellant' \\
\hline \multirow[t]{2}{*}{3.} & Apa yen tolih ngajohang? & kuping \\
\hline & 'What is it, if it is seen so it becomes farther?' & 'ears' \\
\hline \multirow[t]{2}{*}{4.} & Apa medil tanah kena cunguh? & entut \\
\hline & 'What is it, shoot the ground but hit the nose?' & 'fart' \\
\hline \multirow[t]{2}{*}{5 . } & Apa anak cerik mabaju liu? & jagung \\
\hline & 'What is it, small person is wearing many clothes?' & 'corn (Latin: zea mays)' \\
\hline \multirow[t]{2}{*}{6.} & $\begin{array}{l}\text { Apa dugasne cerik mapusungan, nanging sasubane } \\
\text { kelih magambahan? }\end{array}$ & $\begin{array}{l}\text { paku } \\
\text { 'fern (Latin: diplazium esculentum)' }\end{array}$ \\
\hline & $\begin{array}{l}\text { 'What is it, when it was small its hair was twisted, when } \\
\text { it was adult its hair was parsed?' }\end{array}$ & \\
\hline \multirow[t]{2}{*}{7.} & Apa yen majemuh belus, nanging yen maembon tuh? & lengar \\
\hline & $\begin{array}{l}\text { 'What is it, when it is sunbathing it is wet, when it is } \\
\text { sheltering it is dry?' }\end{array}$ & 'bald head' \\
\hline
\end{tabular}

In table 2, there are 7 data of associative cecimpedan. Cecimpedan number 1 - 5 use a single clause whereas numbers 6 - 7 use a plural clause.

\section{B. Semantic-cognitive Process of Onomatope Cecimpedan}

Onomatope is one of the semantic motivation through sound. Onomatope is a stylistic device based on sound modulation reinforced by alliteration, rhythm, assonance, and rhyme. According to many experts, onomatope is often paired with sound replicas, so the relation between meaning and name (word) is interpreted based on an echo according to an acoustic experience which is similar to the phonetic structure of a word (Ullman, 1977; Sumarsono, 2007; Frederiksen, 1977).

Onomatope cecimpedan is constructed by using abbreviation technique that is abbreviate the word by maintaining final syllable of word (like data in table 1 column 1). The final syllable defense aims to produce rhyme (poetry) as the interpretation basis of meaning and word. Bloomfield (1995) asserts that in various languages there is a morphemic rule based on the beginning or final syllables as a significance system of meaning. For example, in Indonesian language, there are some words with final syllable sah, such as: resah 'restlessness', gelisah 'anxiety', susah 'difficulty', desah 'sigh'; as well as the word ending with the final syllable pit, such as: sempit 'narrow', jepit 'pinch', apit 'wedge', impit 'press', and so on. This linguistic fact also occurs in the Balinese language, such as those with the final syllable dag to form the word undag 'ladder of the building', bodag 'big basket', dagdag 'pig fodder', bebedag 'foal', kodag 'capable'; or that resonates sound with [ag], such as: degag 'arrogant', papag 'pick up', ugag 'unload', jegagag 'look up', lempag 'hard hit by using stick'. Such syllabic and sound resonance patterns become the basis of forming onomatope cecimpedan. To strengthen the following analysis, there are some data of it.

TABLE 3.

ONOMATOPE CECIMPEDAN AND SEMANTIC INTERPRETATION

\begin{tabular}{|c|c|c|}
\hline No. & Onomatope Cecimpedan & Semantic Interpretation \\
\hline 1. & $\begin{array}{l}\text { Apa cing dag? } \\
\text { 'What is cing dag?' }\end{array}$ & $\begin{array}{l}\text { Cicing medem di undag } \\
\text { 'Dog is sleeping on stairs' } \\
\text { Cicing medemin bodag } \\
\text { 'Dog is sleeping in a big basket' }\end{array}$ \\
\hline 2. & $\begin{array}{l}\text { Apa pi suk? } \\
\text { 'What is pi suk?' }\end{array}$ & $\begin{array}{l}\text { Sampi matelusuk } \\
\text { 'Nose-tied cow' }\end{array}$ \\
\hline 3. & $\begin{array}{l}\text { Apa nyu luh? } \\
\text { 'What is nyu luh?' }\end{array}$ & $\begin{array}{l}\text { Penyu mataluh } \\
\text { 'Turtle lays her eggs' }\end{array}$ \\
\hline 4. & $\begin{array}{l}\text { Apa krik pa? } \\
\text { 'What is krik pa?' }\end{array}$ & $\begin{array}{l}\text { jangkrik kipa } \\
\text { 'one legged cricket' }\end{array}$ \\
\hline 5. & $\begin{array}{l}\text { Apa kung kek? } \\
\text { 'What is kung kek?' }\end{array}$ & $\begin{array}{l}\text { enggung ngokek } \\
\text { 'frog is voiced' }\end{array}$ \\
\hline
\end{tabular}

The onomatope cecimpedan as the data shown in Tables 1 and 3 prove that phonological instruments are a strong support for semantic interpretation. The production and understanding processes of the onomatope cecimpedan are based on an analogy logic referring to the rhyme and the resonance of the final sound. The production process begins with the targeting of semantics and lexical. In this phase, children select and define two words which is in local culture often pair in a single phrase or core clause. This phase is the utterance plan (Lauria, 1982). The second is the abbreviation phase. In this phase, children delete one or more syllabics of selected words. The result is an abbreviation of the final syllable with the aligned resonance of the sounds. This phase is intended to make semantic gap. In this phase, sound alignment often occurs through phonetic manipulation with the principle of allophones (such as data 5 in table 3 ). The data shows that the final syllable of word enggung 'frog' should be gung but for the resonance is changed with kung so that the consonant $[\mathrm{g}]$ changes to $[\mathrm{k}]$ are both velar consonants. Consonant replacement of $[\mathrm{g}]$ with $[\mathrm{k}]$ is intended to 
obtain a resonance alignment with the syllable kek that follows it. The third, the syntactic phase of canonical sentence formation. In this phase, the cecimpedan is constructed in a sentence according to Balinese syntax rules. This third phase is an inner speech. The fourth is articulation phase, namely cecimpedan pronunciation as a stimulation for speakers and audience. The articulation phase is controlled by lexical and semantic targets. The production process of onomatope cecimpedan can be visualized in the following diagram.

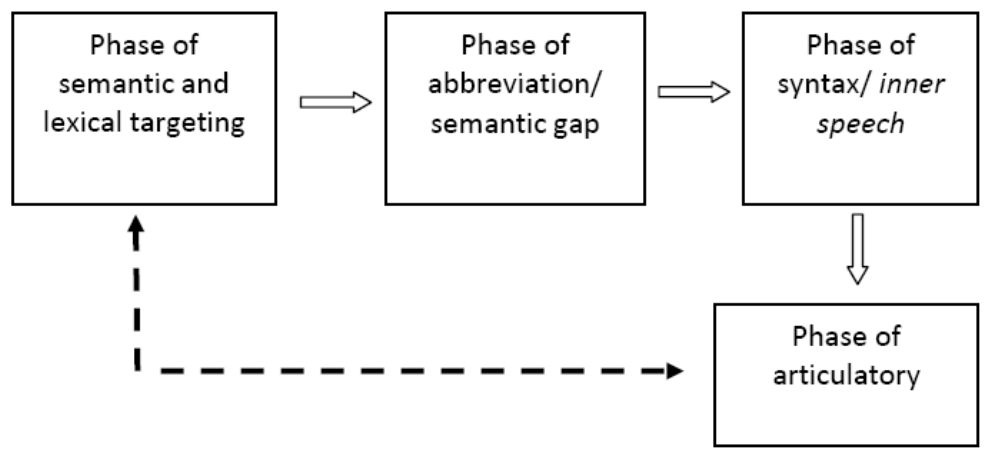

Diagram 2. Semantic-Cognitive Process of Onomatope Cecimpedan Production

Unlike the production process, the comprehension begins with the mental process of onomatope cecimpedan perception that is heard by the children. In this phase, there is a hearing process of cecimpedan. The cecimpedan is a stimulus that encourages cognitive process to compare rhyme or sound resonance with the vocabulary. The second phase is memory evocation to select relevant semantic and lexical. The consideration is based on empirical and cultural knowledge. The third phase is an inductive analogous thinking process, which compares the similarity of rhyme and sound resonance with the vocabulary presented in the cognitive of children. In this phase, there is a sound mapping with its lexical meaning. The fourth phase is the determination of choice and the conclusion of semantic and lexical based on the rhyme and the resonance of the reference sound. The fifth phase is syntax, i.e. constructing selected semantic and lexical into the core of sentence structure. In this phase, children construct the core sentence in response to the cecimpedan that is presented to them. In this phase, a double conclusion is possible, i.e. an onomatope cecimpedan can represent more than one meaning resulting in polysemy, such as data 1 in table 3. Onomatope cecimpedan 'Apa cing dag?' Can be interpreted as Cicing medem di undag 'Dog is sleeping on the stairs' or Cicing medemin bodag 'Dog is sleeping in big basket'. This polysemy occurs because of the final syllable of dag corresponds to the lexicon of undag and bodag which both exist empirically in Balinese culture. The sixth phase is articulation, which provides answers to questionable cecimpedan construction. This final phase is controlled by the perceptive phase. The cognitive process of onomatope cecimpedan understanding can be visualized as follows.

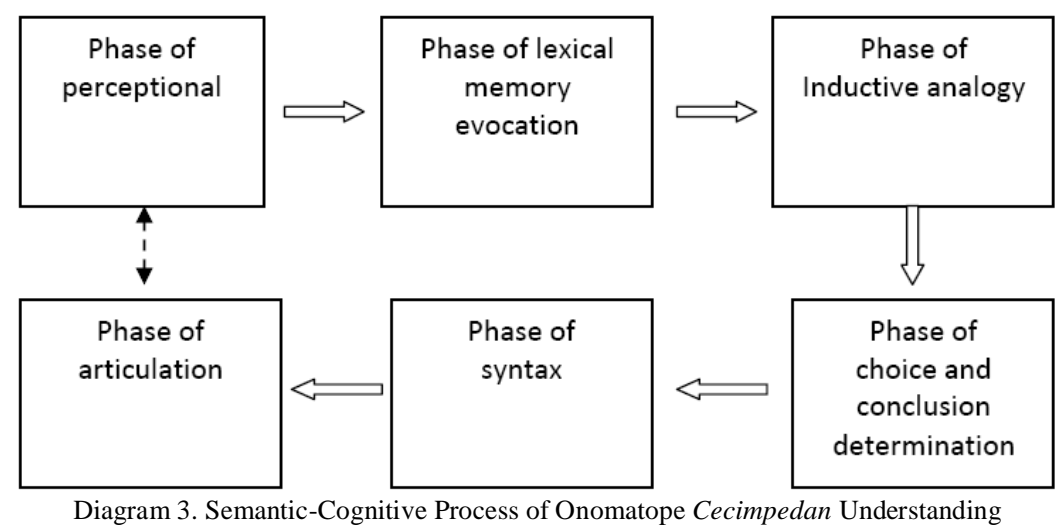

Diagrams 2 and 3 illustrate the different processes that occur in the production and understanding of onomatope cecimpedan. These findings prove that cecimpedan production and understanding involve different cognitive processes (Tantra, 1992, Lauria, 1982). However, the production process and the understanding of onomatope cecimpedan are both based on the same point, that is the meaning based on the echo. Echoes in cecimpedan are used to construct semantic gap; and echoes also become the basis of its interpretation. This linguistic fact suggests that the semantic process of onomatope cecimpedan involves the inductive analogy logic based on the echoes similarity and sound resonance as the production and interpretation basis.

\section{Semantic-cognitive Process of Associative Cecimpedan}

Association is a comparative way of thinking through the attribution of one thing to another. The relationship results in cognitive link. Associative cecimpedan development is based on a declarative analogy (Sumarsono, 2004: Arnawa, 
2016). This model is developed through descriptive paraphrasing techniques, i.e. something is explained into speech or discourse to describe the replaced things, such as the data in table 2. This paraphrase results in a lexical semantic gap that will be guessed by the participants. The production process of associative cecimpedan can be visualized in the following diagram.

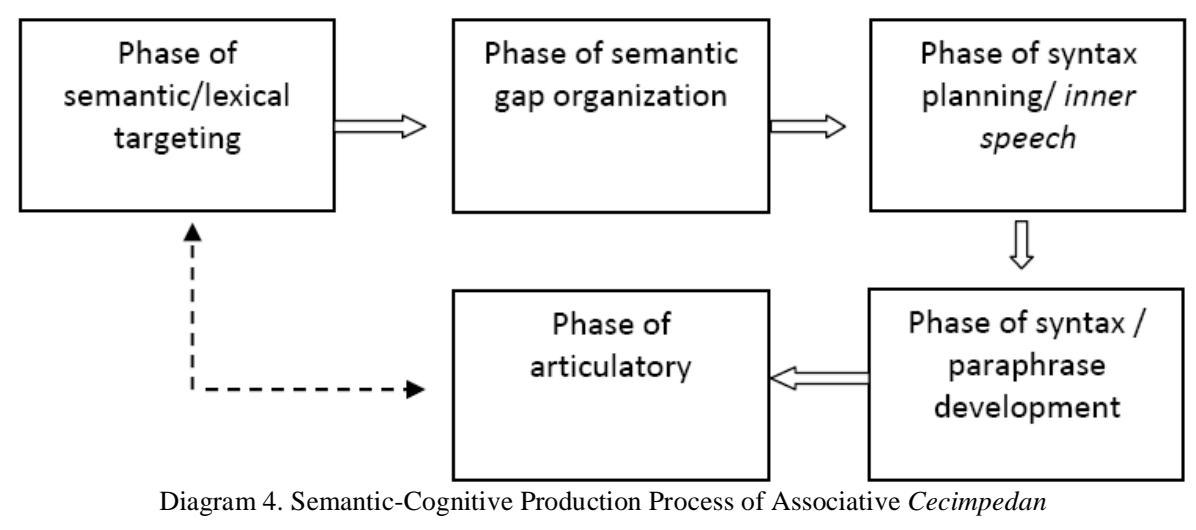

Diagram 4 can be explained as follows. In the first phase, something is set to be the guessing target by children. It can be expressed through a single word, phrase, or core clause. In the second phase, the message is processed by the children to create a cognitive gap, such as data 7 in table 2, i.e. Apa yen majemuh belus, nanging yen maembon tuh? 'What is it, when it is in the sun, it is wet, but when it takes shelter, it is dry? In this cecimpedan, there is the following gap.

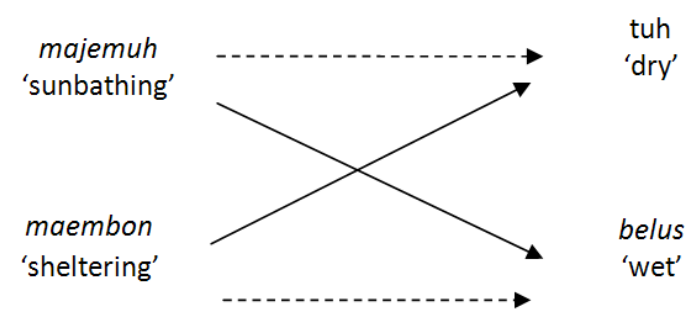

In ordinary language, the adjective majemuh 'sunbathing' is paired with the word tuh 'dry and maembon 'sheltering' is paired with the word belus 'wet'. The word majemuh and maembon and the word tuh and belus are two pairs of anonymous words. However, the associative cecimpedan is logically reversed. This reversal of logic causes semantic gap. In the third phase, the words selection will be assembled into a sentence or organized utterance. Each diction is designed to contain a meaning. This phase is the preparation of sentences or utterances production that will be expressed externally. In the fourth phase, the development of sentences is done by using the selected diction. In this phase, it is designed and defined the construction of the sentence to be used. The fifth phase is an action of pronouncing associative cecimpedan in accordance with a defined syntactic pattern. The spoken sentences are stimulus for the listener to guess the meaning of associative cecimpedan.

The understanding process of cecimpedan is a cognitive activity to interpret the meaning exactly. Therefore, careful understanding of semantic gap and relating them to the daily knowledge and experience is the key of associative cecimpedan interpretation. The meaning understanding of associative cecimpedan begins from the perceptive phase of the heard stimulus. The stimulus understanding leads to the discovery phase of the semantic gap. The semantic gap understanding encourages the thought process of declarative analogy as empirical inequalities explanation. The precision of analogy frames and limits the lexical choice which is likely to be the answer to an associative cecimpedan. Based on the ability to perform a declarative analogy, a lexical is also selected and assigned to be an answer which is further articulated to the cecimpedan producer and other audiences. The understanding process of associative cecimpedan can be visualized as the following diagram. 


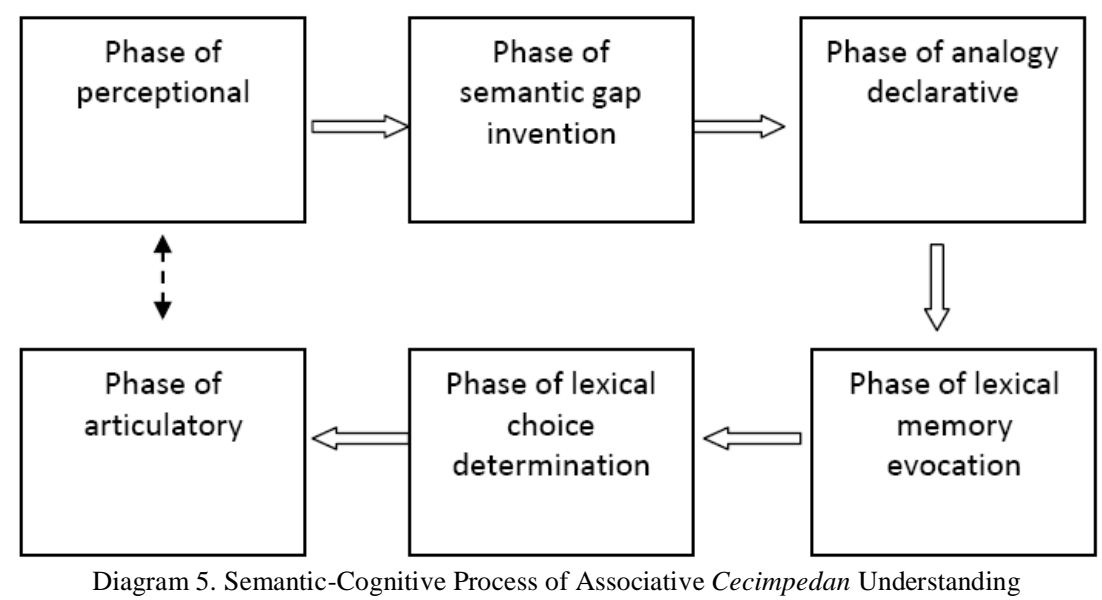

Based on diagrams 4 and 5 it is known that the formation and understanding process of associative cecimpedan depend on the ability of children to think declarative analogy. This ability is a cognitive activity of comparing something to another to express its similarity. The description of something similar is used to describe something else. Therefore, in the competition of cecimpedan, each answer must be explained by the analogy logic of it; For example, data 4 and 7 in table 2 below.

Cecimpedan: Apa medil tanah kena cunguh?

Answer: entut 'flart'

'What is it, shoot the ground but hit the nose?'

Reason: The anus hole leads downwards so that when farting the exit gas is assumed towards the ground, however the smell towards the nose.

Cecimpedan: Apa yen majemuh belus, nanging yen maembon tuh?

'What is it, when it is sunbathing it is wet, when it is sheltering it is dry?'

Answer: lengar 'bald head'

Reason: If the bald person is sunbathing so he/she will sweat so the bald head will be wet; whereas if he/she is sheltering so the sweat bald will be dry.

\section{DISCUSSION}

Cecimpedan is one of the Balinese proverbs commonly used by children in familiar and relaxed situations. Cecimpedan is developed based on the analogy-associate logic so that its semantic interpretation involves cognitive process. Based on the cognitive process, cecimpedan is classified into two, i.e. onomatope and associative cecimpedan. Onomatope cecimpedan is formed and interpreted based on rhyme and sound resonance. Its semantic interpretation involves the reasoning of the inductive analogy, that is comparing the similarity of the final syllable morphological form with the morphological form of a word. Comparison of the word form indicates that the child thinks concrete as the cognitive development of the preoperational phase (Tarigan, 1985; Dardjowidjojo, 2000). Syntactically, onomatope cecimpedan is constructed in a simple question consisting of three words. Based on psycholinguistic studies, the length of utterance can be used as an indicator of children's language development that is an integral part of cognitive development. Based on the utterance length, the linguistic competence of children who is the user of onomatope cecimpedan can be identified in the grammatical development period or phase III. This limitation of linguistic and cognitive competence causes the simplicity of the semantic form and process of onomatope cecimpedan. In lexical semantic theory (Ulmaan, 1977) it is explained that onomatope is an interpreted meaning based on an echo that is heard. The meaning based on this echo becomes the basis of cecimpedan onomatope development. This onomatope phenomenon is often used by children in daily Balinese-speaking activities, such as dog is called kong, pig is called guik; and cat is called ngeong, according to the sound or echo that animal produced.

Associative cecimpedan construction is more complex. This cecimpedan involves a more complex linguistic competence and higher cognitive development. Associative cecimpedan uses a broad sentence, or complex clause, even it is often expressed in paragraph. The average length of the sentence is more than 4 words. The length of this sentence indicates that the users of associative cecimpedan have complete linguistic competence or phase $\mathrm{V}$, and the cognitive developmental level is in the formal operational phase. This development of linguistic and cognitive competence underlies the ability to think logically on the basis of declarative analogy that becomes the meaning process of associative cecimpedan. The use of sensory knowledge and experience is an integral part of the semantic process of this type, so it cannot be separated with a more complex cognitive process. The involvement of development level of the linguistic and cognitive competence causes the production and understanding process of onomatope is different to 
associative cecimpedan. Differences in linguistic competence and cognitive development are often associated with the age of children. However, age is not an absolute barrier to the use of both types of cecimpedan.

\section{CONCLUSION}

In Balinese language, there are two types of cecimpedan, namely onomatope and associative cecimpedan. Its classification is based on a cognitive development hierarchy. The level of cognitive development determines the linguistic competence of children. Onomatope cecimpedan is used by children who are in the preoperational cognitive development period whereas the associative cecimpedan is used by children who are in formal operational period. Differences in the cognitive phase lead to differences in semantic-cognitive processes in those both types. The semantic-cognitive process of onomatope cecimpedan involves the reasoning of an inductive analogy that is based on the actual equality of sounds; whereas associative cecimpedan uses declarative analogy logic constructed through word choices that can describe logical gap. Thus, the classification of cecimpedan is not solely based on the age of the speaker, but also based on cognitive development.

\section{REFERENCES}

[1] Alwi, Hasan., dkk. (2001). Kamus Besar Bahasa Indonesia. Jakarta: Balai Pustaka.

[2] Arnawa, Nengah. (2016). 'Interpretasi Pragmatis Analogis Metafora Bahasa Bali'. In Jurnal Kajian Bali Volume 06, Nomor 01, April 2016, $59-80$.

[3] Bloomfield, Leonard. (1995). Bahasa (Translated by I. Sutikno). Jakara: PT. Gramedia Pustaka Utama.

[4] Chaer, Abdul. (2003). Psikolinguistik. Jakarta: Rineka Cipta.

[5] Crider, B. Andrew; George R. Geothais; Robert D. Kavanaugh; Paul R. Solomom. (1983). Psychology. Dallas: Scott, Foresman and Company.

[6] Dardjowidjojo, Soedjono. (2000). Echa: Kisah Pemerolehan Bahasa Anak Indonesia. Jakarta: Grasindo.

[7] Dardjwidjojo, Soedjono. (2003). Psikolinguistik: Pengantar Pemahaman Bahasa Manusia. Jakarta: Yayasan Obor Indonesia.

[8] Djajasudarma, T. Fatimah. (1993). Metode Linguistik. Bandung: Eresco.

[9] Frederiksen, Carl H. (1977). Semantic Processing Units in Understanding Text. In Roy O. Freedle (eds). Discourse Processes: Advances in Research and Theory. New Jersey: Ablex Publishing Corporation, 57 - 87.

[10] Garman, Michael. (1991). Psycholinguistics. Cambiridge: Cambridge University Press.

[11] Gautama, I Wayan Budha. (1995). Pralambang Basa Bali. Denpasar: CV. Kayu Mas.

[12] Gimblett, Barbara Kirshenblatt. (1976). Children's Tradisional Speech Play and Child Language. In Barbara KirshenblattGimblett (eds). Speech Play. Pennsylvania: University of Pennsylvania Press, 65 - 109.

[13] Ginarsa, Ketut. (1985). Paribasa Bali. Denpasar: CV. Kayu Mas.

[14] Hall, William S., Michael Cole, Stephen Reder and Gillian Dowley. (1977). Variations in Young Children's Use Language. In Roy O. Freedle (eds). Discourse Processes: Advances in Research and Theory. New Jersey: Ablex Publishing Corporation, 161 $-173$.

[15] Hari, Fitria C. dan Indrayani. (2010). 'Aliran Asosiasi'. http://psychology.or.id (acessed, 10 May 2017).

[16] Lauria, Alexander R. (1982). Language and Cognition. New York: V.H. Winston \& Sons, a Division of Scripta Technica, Inc.

[17] Mashun. (2005). Metode Penelitian Bahasa. Jakarta: PT. Radja Grafindo Persada.

[18] Samarin, William J. (1988). Ilmu Bahasa Lapangan. Yogyakarta: Kanisius.

[19] Saussure, Ferdinand de. (1988). Pengantar Linguistik Umum. Yogyakarta: Gadjah Mada University Press.

[20] Sherzer, Joel. (1976). Play Languages: Implications for (Socio) Linguistics. In Barbara Kirshenblatt-Gimblett (eds). Speech Play. Pennsylvania: University of Pennsylvania Press, 19 - 35.

[21] Simpen, A.B. (1988). Basita Parihasa. Denpasar: Upada Sastra.

[22] Sudaryanto. (1993). Metode dan Aneka Teknik Analisis Bahasa. Yogyakarta: Duta Wacana University Press.

[23] Sujiono, Yuliani Nurani, dkk. (2009). Metode Pengembangan Kognitif. Jakarta: Universitas Terbuka.

[24] Sumarsono. (2004). Filsafat Bahasa. Jakarta: Grasindo.

[25] Sumarsono. (2007). Semantik. Yogyakarta: Pustaka Pelajar.

[26] Sund, R. B. (1976). Piaget for Educators: A Multimedia Program. Ohio: Charles E. Merril Publishing Company.

[27] Tantra, D.K. (1992). 'Children's Comprehension and Production of Directive at Ages Six, Seven, and Eight in Bali'. Doctoral disertation. New York State University.

[28] Tarigan, H.G. (1985). Psikolinguistik. Bandung: Angkasa.

[29] Tinggen, I Nengah. (1995). Aneka Rupa Paribasa Bali. Singaraja: Rikha Dewata.

[30] Ullman, Stephen. (1977). Semantics: An Introduction to The Science of Meaning. Oxford: Basil Blackwell. 
Nengah Arnawa was born in Jinengdalem, Singaraja, Bali, Indonesia on December $24^{\text {th }}, 1965$. He had completed his doctoral education in 2005. The areas of his interest are semantics, pragmatics, and language philosophy. Since November $1^{\text {st }}, 2002$, he was appointed as head lecturer at IKIP PGRI Bali in Semantic of Indonesian Language. The resulting articles, such as: "Meaning Truth Explication Language Philosophy: A Multicultural Communication Dimension" (2015); "Children Indirect Speech Acts at Ages 18-24 Month Old: A Case Study on Indonesian Language Acquisition by Balinese Children" (2016); "Shift of Balinese Language Vocabulary of Agriculture: A Study on Anthrophological Linguistics (2016). Interpretation of Pragmatic Analogical Balinese Metaphors" (2016); "The Implementation of Natural Semantic Metalanguage and Semantic Filed in Language Teaching: A Case Study" (2017). Currently, He is studying "Balinese Hegemonic Politeness in Awig-Awig", with the expense of the Directorate General of Higher Education, Ministry of Research, Technology and Higher Education.

Nengah Arnawa is an active member of Masyarakat Linguistik Indonesia (MLI) "Indonesian Linguistics Society"; Asosiasi Peneliti Bahasa Lokal (APBL) "Association of Local Language Researchers", and as a member of the Management Association of Study Program of Indonesian Language and Literature. 